\title{
Redescription of Schizodon dissimilis and appraisal of the dark barred species of the genus (Characiformes: Anostomidae)
}

\author{
Júlio Cesar Garavello ${ }^{1}$ and Heraldo Antonio Britski ${ }^{2}$
}

Schizodon dissimilis is redescribed on the basis of syntypes and non-type specimens from the Parnaíba, Jaguaribe and Mearim rivers, and lectotype and paralectotypes are designated. Schizodon dissimilis is distinct from the Amazonian and southeastern Brazil congeners by having four dark brown vertical bars without a midlateral dark brown stripe or a dark blotch on caudal peduncle. When compared with the northeastern Brazilian Schizodon and those from the São Francisco river, and with the remaining dark barred species S. australis, S. borellii, S. corti, S. fasciatus and S. intermedius, it is diagnosed by a combination of lateral line scale counts, color pattern and body proportions. The color pattern distinguishes $S$. dissimilis from S. fasciatus and the meristic and morphometric data are important in separating $S$. dissimilis from $S$. intermedius and $S$. borellii. Schizodon dissimilis and S. fasciatus have disjunct distributions, with the first occurring in northeastern basins, and the second widely distributed through the Amazon basin and rivers draining northward from the Guyana Shield. Schizodon intermedius and $S$. borellii are respectively native to the upper Paraná and Paraguay river basins while S. australis is known from the Paraná-Uruguay system and $S$. corti was described from Maracaibo, Venezuela.

Keywords: Anostomidae, Brazil, Rio Parnaíba, Species, Taxonomy.

Schizodon dissimilis é redescrita com base em síntipos e outros espécimes coletados nos rios Parnaíba, Jaguaribe e Mearim, e um lectótipo e paralectótipos são designados. Schizodon dissimilis é distinta das espécies Amazônicas e de seus congêneres do sudeste do Brasil por possuir quatro barras transversais castanho-escuras sem uma listra longitudinal mediana ou mácula escura no pedúnculo caudal. Quando comparada com as espécies de Schizodon do nordeste brasileiro e do rio São Francisco, assim como com as demais espécies com barras transversais escuras $S$. australis, S. borellii, S. corti, S. fasciatus e S. intermedius, se distingue pela combinação da contagem de escamas da linha lateral com padrão de colorido e proporções corporais. $O$ padrão de colorido separa definitivamente $S$. dissimilis de $S$. fasciatus, enquanto os dados merísticos e morfométricos são importantes para distinguir $S$. dissimilis de $S$. intermedius e $S$. borellii. Schizodon dissimilis e $S$. fasciatus têm distribuição disjunta, a primeira nativa dos rios da região nordeste e a segunda amplamente distribuída pela Bacia Amazônica e Guiana. Schizodon intermedius e $S$. borellii são nativas das bacias do alto rio Paraná e do rio Paraguai respectivamente, enquanto e $S$. australis é conhecida da bacia Paraná-Uruguai e $S$. corti foi descrita do Lago Maracaibo na Venezuela.

Palavras-chave: Anostomidae, Brasil, Espécies, Rio Parnaíba, Taxonomia.

\section{Introduction}

The anostomid genus Schizodon was created by Agassiz for the species $S$. fasciatus described by Spix, Agassiz (1829) from Brazilian rivers. In his revision of anostomid fishes, Myers (1950) recognized Schizodon as a genus with eight serrate teeth on each jaw. That dental character remained the diagnostic feature for Schizodon until recently, when Sidlauskas, Vari (2008) added that the second and third teeth of premaxilla have four cusps, and the distal margin of the main lobe of the symphyseal dentary tooth has three distinct cusps. Those authors also proposed two osteological synapomorphies for Schizodon, the wide ascending process of the anguloarticular and a torsion in the medial flange of the mesocoracoid. Although the genus is broadly accepted and relatively well defined, its species-level taxonomy and relationships still need further study.

Schizodon currently comprises fifteen species: $S$. fasciatus Spix, Agassiz, 1829, S. vittatus (Valenciennes, 1850), S. isognathus Kner, 1858, S. nasutus Kner, 1858, S. knerii (Steindachner, 1875), S. dissimilis (Garman, 1890), S. platae (Garman, 1890), S. borellii (Boulenger, 1900), S. rostratus (Borodin, 1931), S. corti Schultz, 1944,

${ }^{1}$ Departamento de Ecologia e Biologia Evolutiva, Universidade Federal de São Carlos, Rodovia Washington Luiz, km 235, Caixa Postal 676, 13565-905 São Carlos, SP, Brazil. garavelo@ufscar.br, Ohttps://orcid.org/0000-0003-2985-6665 (corresponding author)

${ }^{2}$ Seção de Peixes, Museu de Zoologia da Universidade de São Paulo, Caixa Postal 42494, Av. Nazaré, 481, Ipiranga, 04218-970 São Paulo, SP, Brazil. heraldo@usp.br, Ohttps://orcid.org/0000-0002-5593-9651 
S. jacuiensis Bergmann, 1988, S. altoparanae Garavello, Britski, 1990, S. intermedius Garavello, Britski, 1990, S. australis Garavello, 1994, and S. scotorhabdotus Sidlauskas, Garavello, Jellen, 2007. Previously, species groups of Schizodon were identified on the basis of color pattern by Géry (1977), Garavello, Britski (1990), Garavello (1994) and Sidlauskas et al. (2007). Vertical dark brown bars on the flanks characterize the $S$. fasciatus group, which also includes $S$. australis, $S$. borellii, $S$. corti, $S$. dissimilis and $S$. intermedius.

Garman (1890) described Schizodon dissimilis from material collected by the Thayer Expediton in the rio Puty [Poti] in northeastern Brazil. Subsequent authors such as Fowler (1941) and Roberts (1973) created some confusion by identifying Schizodon from northeastern Brazil as S. fasciatus. Furthermore, Géry et al. (1987) identified specimens from the Parana-Paraguay river basin as Schizodon aff. dissimile even though Boulenger (1900) had previously described $S$. borellii from that basin. The original description of $S$. dissimilis is brief and does not compare that species with $S$. fasciatus. In the years that followed, these dark-barred species of the genus have never been redescribed, with the lack of clear diagnoses resulting in several misidentifications.

A redescription of Schizodon dissimilis (Garman, 1890) is needed, and indeed overdue. In this study, we evaluate the members of Schizodon fasciatus species group and redescribe Schizodon dissimilis (Garman, 1890) based on examination of the syntypes of this species from the rio Poti and additional specimens from the rivers Parnaíba, Poti, Jaguaribe and Mearim.

\section{Material and Methods}

Taxonomic analysis: Institutional abbreviations include: Museum of Comparative Zoology (MCZ); National Museum of Natural History, Smithsonian Institution (USNM); Museu de Zoologia da Universidade de São Paulo (MZUSP); Museu Nacional Universidade Federal do Rio de Janeiro (MNRJ); The Academy of Natural Sciences of Philadelphia (ANSP); Field Museum of Natural History (FMNH); Museu de Ciências e Tecnologia, Pontifícia Universidade Católica do Rio Grande do Sul (MCP); Laboratório de Ictiologia Sistemática do Departamento de Ecologia e Biologia Evolutiva da Universidade Federal de São Carlos (LISDEBE); Coleção de Peixes do Departamento de Oceanografia e Limnologia da Universidade Federal do Maranhão (CPDOL), and Departamento de Sistemática e Ecologia da Universidade Federal da Paraíba (UFPB).

Meristic and morphometry were taken on four commonly misidentified species in the Schizodon fasciatus group ( $S$. dissimilis, $S$. fasciatus, $S$. borellii and S. intermedius) following Garavello (1994). Meristics included counts of premaxillary and dentary teeth, and counts of scales in the lateral line, predorsal series, transverse series, preanal series and circumpeduncular series. Measurements taken point-to-point with the help of digital calipers included: standard length, head length, trunk length, body depth, predorsal distance, snout length, interorbital distance, orbital diameter, caudal peduncle depth, first anal-fin ray length, ninth anal-fin ray length, interopercular distance, head depth, premaxillary length and mandibular width. Head length was taken from the tip of the snout to the posterior bony margin of the opercle. Meristic and morphometric characters were obtained for a total of 107 specimens of $S$. dissimilis ( $\mathrm{n}=26$ specimens) $S$. fasciatus $(\mathrm{n}=28) ; S$. borellii $(\mathrm{n}=27)$ and $S$. intermedius $(\mathrm{n}=26)$.

Multivariate morphometric analysis: Principal component analysis (PCA) was used to explore morphometric differences between $S$. borellii, $S$. dissimilis, $S$. fasciatus and $S$. intermedius. In this analysis fifteen measurements were taken on 81 specimens of $S$. dissimilis $(\mathrm{n}=13)$, S. fasciatus $(15)$, S. borellii $(\mathrm{n}=27)$ and $S$. intermedius $(\mathrm{n}=26)$. PCA was performed on the natural logarithms of the measurements using the covariance matrix in accordance with Bookstein et al. (1985) and sheared thereafter in accordance with Macleod (1990). This sheared principal component analysis (PCA) removes the influence of a general size factor on the second principal component axis (PC2) and subsequent axes (Humphries et al., 1981). The eigenvectors resulting from the shearing procedure were analyzed to determine whether the species considered in the analysis differ in shape. Results of the sheared PCA on component axes II and III are represented by a scatterplot graph, while meristic and morphometric data on $S$. dissimilis and $S$. fasciatus are presented in a separate table.

\section{Results}

In the unsheared principal component analysis, PC1 explained $93.9 \%$ of the total variance. PC2 and PC3 explained 1.7 and $1.5 \%$ of the total variance, respectively (Tab. 1). After shearing, PC2 alone failed to discriminate between the four species analyzed $(S$. borellii, $S$. dissimilis, S. fasciatus, S. intermedius); however, a scatterplot of the sheared PC2 and sheared PC3 (Fig. 1) separated $S$. intermedius from the other three species, and separated $S$. dissimilis from $S$. intermedius and $S$. borellii. Measurements loading most heavily on the sheared PC2 were: ninth anal-fin ray length $(-0.66)$ and pre-maxillary length $(0.40)$, and in the PC3 were: ninth anal-fin ray length (0.52), body depth (-0.47), head depth $(-0.37)$, orbital diameter $(0.33)$, first anal-fin ray length $(-0.28)$, caudal peduncle depth $(-0.24)$, and head length $(0.23)$ (Tab. 2). Although there are no conspicuous morphometric differences between $S$. dissimilis and $S$. fasciatus, the latter is readily distinguished by the presence of a dark brown blotch on the base of caudal peduncle that is absent in the other three species. 
Tab. 1. Eigenvalues (prior to shearing) obtained from the PCA analysis on specimens of Schizodon fasciatus, $S$. borellii, S. dissimilis and S. intermedius.

\begin{tabular}{cccc}
\hline PC & Eigenvalues & Total Variance (\%) & Total Variance (cumulative \%) \\
\hline 1 & 0.188 & 93.869 & 93.869 \\
2 & 0.003 & 1.741 & 95.610 \\
3 & 0.003 & 1.536 & 97.146 \\
4 & 0.001 & 0.650 & 97.796 \\
5 & 0.001 & 0.541 & 98.337 \\
6 & 0.001 & 0.367 & 98.704 \\
7 & 0.001 & 0.295 & 98.999 \\
8 & 0.001 & 0.288 & 99.287 \\
9 & 0.000 & 0.199 & 99.485 \\
10 & 0.000 & 0.178 & 99.663 \\
11 & 0.000 & 0.109 & 99.772 \\
12 & 0.000 & 0.096 & 99.868 \\
13 & 0.000 & 0.074 & 99.942 \\
14 & 0.000 & 0.056 & 99.998 \\
15 & 0.000 & 0.002 & 100.000 \\
\hline
\end{tabular}

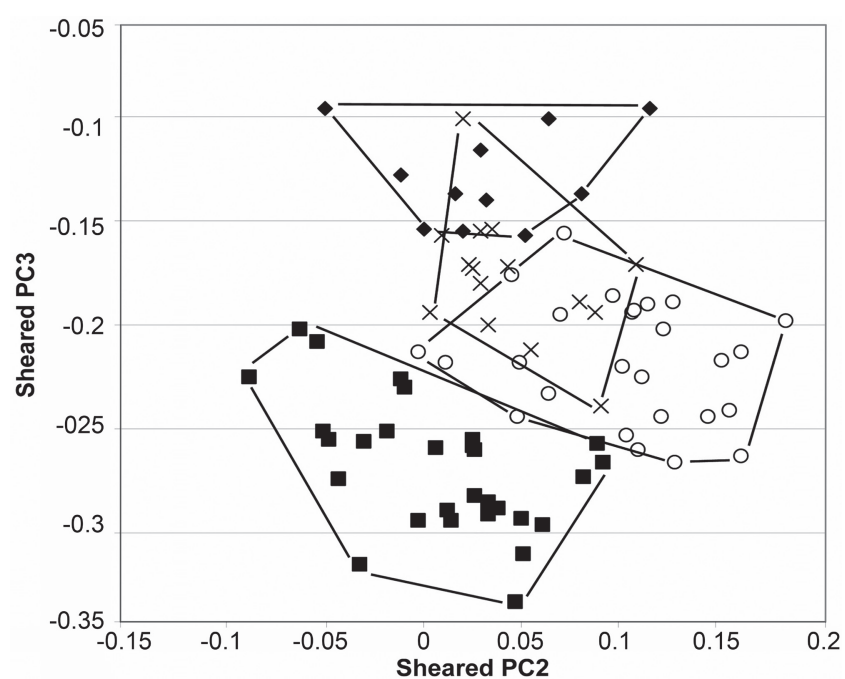

Fig. 1. Scatterplot of the individual scores of combined samples of Schizodon fasciatus (X), S. borellii (white circles); S. dissimilis (diamonds), and S. intermedius (black squares) on the second and third axis of the sheared principal component analysis (PCA).
Tab. 2. Sheared Principal Component loadings of the morphometric measurements used in the Principal Component Analysis. Higher absolute values are bolded.

\begin{tabular}{lccc}
\hline & PC1 & Sheared PC2 & Sheared PC3 \\
\hline Standard Length & 0.283544 & -0.087064 & 0.074955 \\
Head Length & 0.218899 & 0.265713 & $\mathbf{0 . 2 2 5 1 3 4}$ \\
Trunk Length & 0.302780 & -0.179809 & 0.030140 \\
Body Depth & 0.293461 & -0.277325 & $\mathbf{- 0 . 4 7 6 2 1 9}$ \\
Predorsal Distance & 0.265318 & -0.064187 & 0.031645 \\
Snout Length & 0.237604 & 0.268034 & 0.140213 \\
Interorbital Width & 0.254211 & 0.233138 & 0.108246 \\
Orbital Diameter & 0.143506 & 0.148294 & $\mathbf{0 . 3 2 9 1 4 8}$ \\
Caudal Peduncle Depth & 0.287480 & -0.091232 & $\mathbf{- 0 . 2 3 6 1 2 5}$ \\
First Anal-fin Ray Length & 0.245027 & 0.176532 & $\mathbf{- 0 . 2 8 3 4 4 8}$ \\
Ninth Anal-fin Ray Length & 0.266110 & $\mathbf{- 0 . 6 6 0 0 6 0}$ & $\mathbf{0 . 5 2 0 6 0 1}$ \\
Interopercle Width & 0.259344 & 0.043355 & 0.018184 \\
Head Depth & 0.275712 & -0.037075 & $\mathbf{- 0 . 3 7 3 7 2 8}$ \\
Premaxillary Length & 0.249265 & $\mathbf{0 . 4 0 8 1 1 9}$ & 0.167753 \\
Mandibular Width & 0.250833 & 0.123647 & -0.004244 \\
\hline
\end{tabular}

\section{Schizodon dissimilis (Garman, 1890)}

(Figs. 2, 3)

Anostomus dissimilis Garman, 1890: 22 [original description; type-locality: rio Puty (=Poti), Brazil]. - Borodin, 1931: 44 [syntypes examined, rio Poti]. —Vari, Howe 1991: 4 [literature reference]. —Gómez, Chebez, 1996: 53 [literature reference].

Schizodon dissimilis. —Eigenmann, 1910: 425 [rio Poti, Piauí, Brazil]. -Fowler, 1954: 211 [catalogue]. -Garavello, Britski in Reis et al., 2003: 80 [catalogue]. - Britski, Garavello in Buckup et al., 2007: 27 [catalogue]. - Abreu et al., 2009: 8 [rio Poti, Teresina, Piauí]. —Ramos et al., 2014: 3 [rio Parnaíba].

Schizodon fasciatus. - Fowler, 1941: 175 [rio Jaguaribe, Russas, Ceará, Brazil]. - Roberts, 1973: 226-227 [rio Parnaíba, Barra do Longá, near Buriti dos Lopes, Piauí, Brazil]. Sales, Nogueira, Lopes, 1984: 57-62 [açude Joaquim Távora, Jaguaribe, Ceará].

Schizodon dissimile. - Géry, 1987: 154 (literature reference).

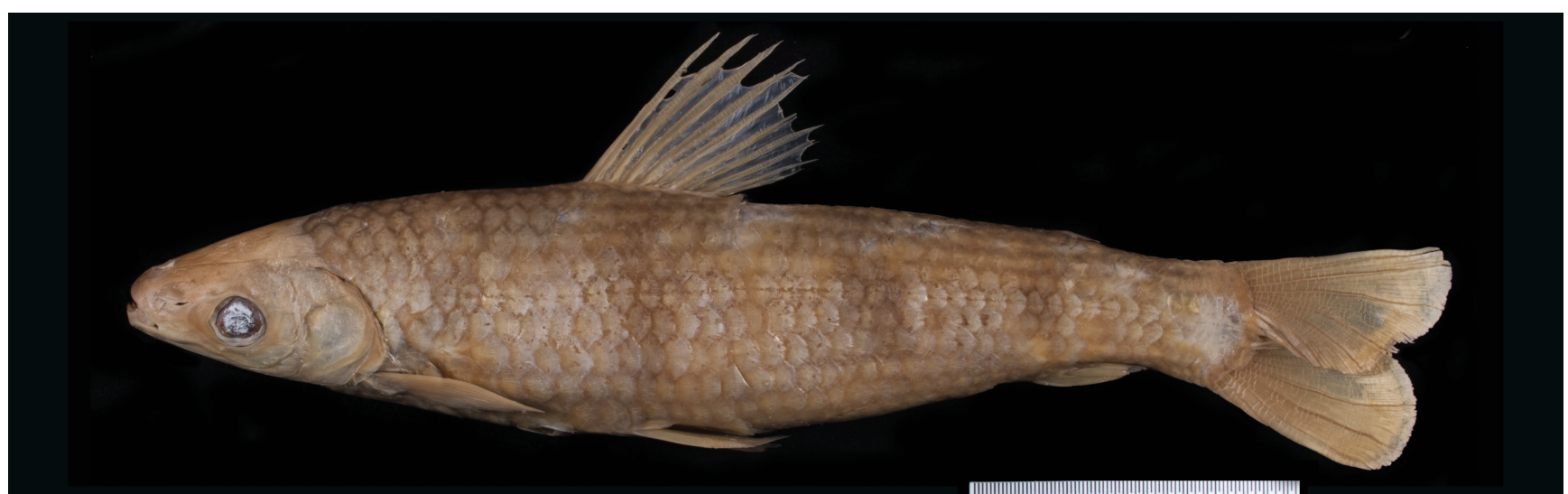

Fig. 2. Schizodon dissimilis, MCZ 19383, Lectotype 264.6 mm SL, rio Poti, Piauí state. 


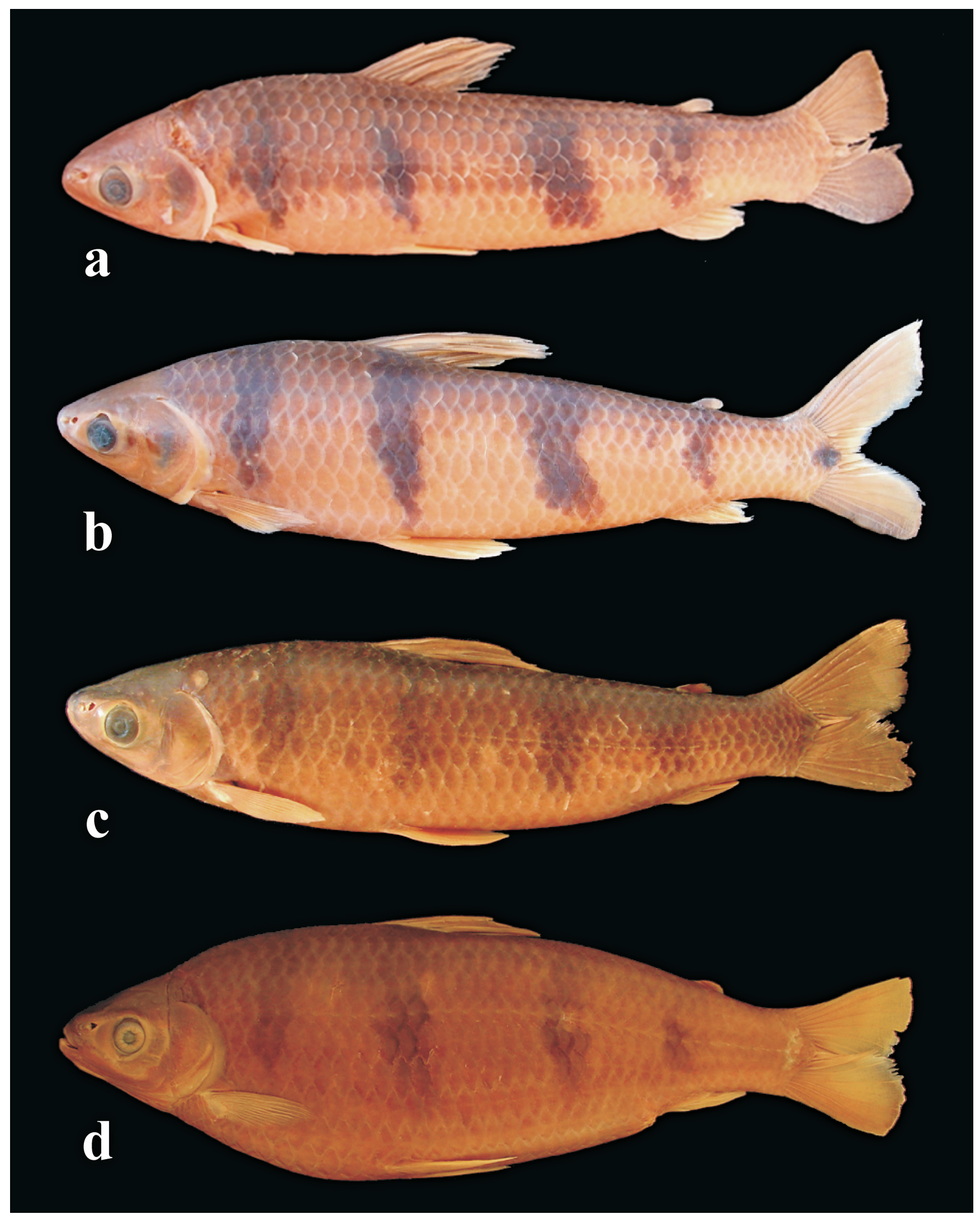

Fig. 3. Schizodon species. (a) Schizodon dissimilis, MZUSP 55143, 220.0 mm SL, rio Jaguaribe, Lima Campos, Ceará state; (b) Schizodon fasciatus, LISDEBE 6981, 275.0 mm SL, rio Solimões, lake Janauacá, Amazonas state; (c) Schizodon borellii, LISDEBE 6977, 245.0 mm SL, Ilha Taiamã, rio Paraguay, Mato Grosso state; (d) Schizodon intermedius, LISDEBE 6984, 233.0 mm SL, rio Jacaré Guaçu, Tietê river basin, São Paulo state. 
Diagnosis. Schizodon dissimilis is a member of the Schizodon fasciatus species group distinguished by having four conspicuous dark brown bars along the trunk and lacking any sort of dark stripe or elongate blotch along the lateral-line scale row $v s$. having a dark midlateral stripe running from the opercle to the caudal peduncle (some specimens of $S$. knerii, S. isognathus, S. scotorhabdotus and $S$. nasutus) or from the vertical through the dorsalfin origin to the caudal peduncle ( $S$. vittatus, and some specimens of $S$. knerii, S. altoparanae and S. jacuiensis); or a dark elongate blotch on caudal peduncle (S. altoparanae, $S$. nasutus, $S$. platae, $S$. rostratus and some specimens of S. knerii). Schizodon dissimilis is distinguished by other members of the $S$. fasciatus species group by having 42-43 lateral-line scales vs. 40-42 in S. borellii and S. intermedius, 44-45 in S. fasciatus and S. corti, 44-46 in S. australis. It is further distinguished from $S$. australis by possessing 4 transverse scale rows above and $4-4.5$ below the lateral line (vs. 5.5/5.5 in S. australis). Schizodon dissimilis is further distinguished from $S$. australis, $S$. corti and $S$. fasciatus by the lack of a dark blotch on the base of the caudal peduncle (vs. the presence of such a blotch in S. australis, S. corti and $S$. fasciatus). Schizodon dissimilis is distinguished by S. intermedius in relative values of body depth in SL (3.9 to 4.9 , mean 4.0 in $S$. dissimilis vs. 2.9 to 3.9 , mean 3.5 in $S$. intermedius). The color pattern of $S$. dissimilis is most similar to that of $S$. intermedius and $S$. borellii, and the meristic characters of $S$. dissimilis and $S$. borellii overlap partially. Despite the morphological similarity between these species, both are considered distinct herein based on their morphometric separation in the sheared PCA and their allopatric distribution. Molecular data are also informative on the distinction among $S$. dissimilis, S. fasciatus, $S$. borellii and $S$. intermedius (see discussion section below).

Description. Morphometric and meristic data of S. dissimilis are presented in Tab. 3. Body fusiform; greatest body depth at or just anterior to dorsal-fin origin. Dorsal profile of head gently curved from snout tip to vertical through anterior margin of eye, rising nearly straight to vertical through posterior margin of opercle, then leveling off to dorsal-fin origin; predorsal region from vertical through posterior margin of opercle to dorsal-fin base slightly convex, forming gentle hump; dorsal-fin base straight, slightly descending; profile from dorsal-fin to adipose fin straight, descending more gradually than dorsal-fin base; caudal peduncle slightly concave. Ventral profile from lower jaw to anal-fin insertion slightly convex with point of maximum inflection at pelvic-fin insertion; base of anal-fin straight, ascending; caudal peduncle slightly concave.

Mouth small, upper and lower jaws horizontally aligned with median region of orbit when the mouth is closed. Upper and lower lips smooth. Maxillary slightly curved along ventral margin and widening posteriorly into a flat rhomboidal plate. Each premaxillary and dentary with four serrate teeth $(n=26$ including lectotype), forming serrated cutting edge. Teeth slightly graded in size; symphysal teeth largest on each jaw; most distant tooth from symphysis much smaller. Anterior and posterior nostrils horizontally aligned with upper lip and upper quarter of orbit. Infraorbitals large; supraorbital positioned at anteriodorsal margin of orbit. Branchiostegal rays and opercular membrane connected at isthmus.

Tab. 3. Morphometrics of Schizodon dissimilis and S. fasciatus expressed as percentages of SL and HL. Meristic data with numbers of specimens with each count in parenthesis. All lectotype data in millimeters.

\begin{tabular}{|c|c|c|c|c|c|c|c|c|c|}
\hline & & \multicolumn{4}{|c|}{ Schizodon dissimilis $(\mathrm{n}=26)$} & \multicolumn{4}{|c|}{ Schizodon fasciatus $(\mathrm{n}=28)$} \\
\hline & \multirow{2}{*}{$\begin{array}{c}\text { Lectotype } \\
\text { MCZ } 19383\end{array}$} & \multicolumn{2}{|c|}{ Range } & \multirow{2}{*}{ Mean } & \multirow{2}{*}{ SD } & \multicolumn{2}{|c|}{ Range } & \multirow{2}{*}{ Mean } & \multirow{2}{*}{ SD } \\
\hline & & Min & Max & & & Min & Max & & \\
\hline Standard length (mm) & 264.6 & 141.0 & 292.0 & 205.6 & 41.477 & 110.0 & 275.0 & 172.6 & 56.879 \\
\hline \multicolumn{10}{|c|}{ Percents of SL } \\
\hline Head length & 62.1 & 21.79 & 26.06 & 23.92 & 1.2923 & 21.25 & 26.91 & 24.16 & 1.7086 \\
\hline Trunk length & 202.5 & 73.94 & 78.21 & 76.18 & 1.2055 & 73.09 & 78.75 & 75.75 & 1.7710 \\
\hline Body depth & 62.7 & 19.88 & 29.03 & 25.41 & 3.0317 & 21.15 & 27.22 & 24.26 & 1.7799 \\
\hline Predorsal length & 112.4 & 39.97 & 44.51 & 42.60 & 1.2893 & 40.00 & 48.00 & 43.27 & 2.1021 \\
\hline Caudal peduncle depth & 27.4 & 9.21 & 12.97 & 10.93 & 1.2262 & 9.40 & 12.34 & 10.12 & 0.7300 \\
\hline \multicolumn{10}{|c|}{ Percents of HL } \\
\hline Snout length & 25.4 & 34.30 & 44.00 & 41.27 & 2.6247 & 38.57 & 42.36 & 40.63 & 0.9773 \\
\hline Interorbital width & 31.1 & 44.28 & 58.84 & 53.84 & 4.3804 & 47.42 & 54.90 & 50.16 & 2.2812 \\
\hline Orbital diameter & 13.3 & 19.45 & 26.59 & 23.09 & 1.7282 & 19.44 & 28.21 & 23.70 & 3.1309 \\
\hline Meristics & & \multicolumn{4}{|c|}{ Schizodon dissimilis $(\mathrm{n}=26)$} & \multicolumn{4}{|c|}{ Schizodon fasciatus $(\mathrm{n}=28)$} \\
\hline Lateral-line scales & 43 & \multicolumn{4}{|c|}{$42(8)-43(17)-44(1)$} & \multicolumn{4}{|c|}{$44(23)-45(5)$} \\
\hline Transverse scales & $4 / I / 4$ & \multicolumn{4}{|c|}{ 4/I/4 (23) - 4.5/I/4 (3) } & \multicolumn{4}{|c|}{ 4/I/4 (all) } \\
\hline Predorsal scales & 11 & \multicolumn{4}{|c|}{$11(19)-12(6)-13(1)$} & \multicolumn{4}{|c|}{12 (all) } \\
\hline Preanal scales & 35 & \multicolumn{4}{|c|}{$33(7)-34(11)-35(8)$} & \multicolumn{4}{|c|}{$35(4)-36(20)-37(4)$} \\
\hline Circumpeduncular scales & 16 & \multicolumn{4}{|c|}{$16($ all $)$} & \multicolumn{4}{|c|}{$16($ all $)$} \\
\hline Teeth counts (pmx/dentar) & $4 / 4$ & \multicolumn{4}{|c|}{ 4/4 (all) } & \multicolumn{4}{|c|}{ 4/4 (all) } \\
\hline
\end{tabular}


All specimens of $S$. dissimilis $(\mathrm{n}=26$ including lectotype) with one extremely small anterior unbranched ray in dorsal fin followed by two major unbranched rays and seven branched rays with the first one longest. Anal fin with two unbranched rays, the first shorter than the second, followed by eight branched rays; first branched anal-fin ray slightly longer than unbranched rays; posterior margin of anal-fin slightly convex. Fleshy cover at base of anterior dorsal and anal fin rays extended. Pectoral fin with two unbranched and 15 branched rays; shape of extended pectoral fin almost triangular. Pelvic fin with one unbranched and eight branched rays; origin at vertical through base of first or second branched dorsalfin ray. Adipose fin elongate, length approximating three dorsal scales; origin at vertical through base of first or second branched anal-fin ray. Caudal fin with 10 principal rays; rays heavily ramified in adults; lobes blunt with rounded margins.

Lateral line scales: 42-43 (43 in lectotype). All lateral line scales pored, including those over caudal-fin rays; sixteen regular scale series around caudal peduncle just posterior to adipose-fin insertion in all specimens including lectotype. Four major scale rows dorsal to lateral line and 4 to 4.5 below lateral line at dorsal fin origin (lectotype 4/I/4); incomplete series of scales on base of dorsal and anal fins; predorsal scales 11-12 (11 in lectotype); scales in preanal series 33-35 (35 in lectotype); circumpeduncular scales series 16 (including the lectotype).

Color in alcohol. Overall ground color brown dorsal to lateral line between opercle and caudal peduncle, light yellowish beginning one or two scale series ventral to lateral line, abdomen and lower caudal peduncle especially pale. Dorsal surface of head brown; ventral surface of head, gular region and branchiostegal membrane yellowish. Sides with four distinct inclined dark brown vertical bars; intensity of dark brown coloration varies among specimens, but number of bars always four. First bar about five scales anterior to dorsal-fin insertion; second bar ventral to dorsal-fin insertion; third situated between end of dorsal-fin base and adipose-fin origin; fourth ventral to adipose fin insertion. First and fourth bars three or four scales wide, second bar two scales wide, third bar two or three scales wide. Opercle brown with hyaline fleshy flap. Unbranched rays of anal, pectoral and pelvic fins occasionally with dark melanophores; fins otherwise hyaline, including adipose fin. Caudal fin with superior lobe slightly brown and inferior lobe conspicuously brown.

Geographic distribution. Schizodon dissimilis is known from Parnaíba, Poti, Mearim and Jaguaribe rivers in Ceará, Piauí and Maranhão states of northeastern Brazil (Fig. 4).

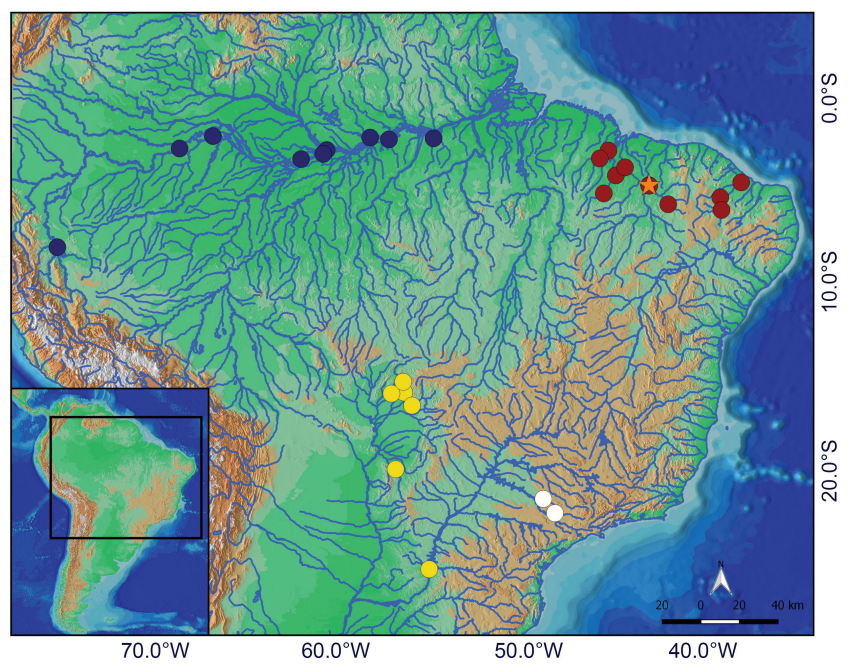

Fig. 4. Location of the lots containing the studied species: Schizodon dissimilis (red, orange star marks the typelocality), S. fasciatus (dark blue), S. borellii (yellow) and $S$. intermedius (white); each symbol may represent more than one sample.

Designation of lectotype. The Thayer Expedition (1865-66) collected 12 specimens from the rio Puty (= Poti), Parnaíba basin, Piauí state, Brazil that were described by Garman (1890) as Anostomus dissimilis without indicating a holotype. One of the largest and better preserved of the syntypes, MCZ 19383, $264.6 \mathrm{~mm} \mathrm{SL}$, is herein designated the lectotype. The remaining specimens are consequently paralectotypes: $\mathrm{MCZ}$ 19381, 5 specimens (3 measured, 152.0, 225.0 and 260.0 mm SL); MCZ 19382, 2 specimens (1 measured $252.5 \mathrm{~mm}$ SL); MCZ 19384, 1 specimen (not measured) and the USNM 120238, 3 specimens (166.0, 172.0 and $211.0 \mathrm{~mm} \mathrm{SL}$ ).

Non-type material: Brazil: Ceará: ANSP 69491, 3, 40.0-80.0 mm SL, Russas, rio Jaguaribe, R. von Ihering, 1936; ANSP 69494, 1, (c\&s), Russas, rio Jaguaribe, R. von Ihering, 1936; MZUSP 55143, 4, 196.0-220.0 mm SL, rio Jaguaribe, 8 Dec 1998, F. A. Bockmann \& P. M. Araujo; MZUSP 55144, 1, 155.0 mm SL, Lima Campos, rio Jaguaribe, creek São João, downstream of Lima Campos dam, 7 Dec 1998, F. A. Bockmann, P. M. Araujo; MZUSP 35763, 4, 195.0-292.0 mm SL, Ceará State, Jul 1983, Departamento Nacional de Obras Contra as Secas (DNOCS). Maranhão: MZUSP 21386, 4, 141.0 249.0 mm SL, Pedreiras, 5 Jan 1955, P. E. Vanzolini; MZUSP 5074, 1, 272.0 mm SL, Barra do Corda, rio Corda, 16 Jun 1966, Expedição Departamento de Zoologia; MZUSP 3558, 1, $185.0 \mathrm{~mm}$ SL, dam at riacho Sangue, Solonópolis, 22 Oct 1944, R. S. Menezes; MNRJ 51527, 1, $181.0 \mathrm{~mm} \mathrm{SL}$, rio Mearim, no date, DNOCS (n/c 15); CPDOL 98287, 10, 155.0-187.0 mm SL, Ilha das Pedrinhas, Lago de Viana, rio Pindaré-Mearim system, 8-14 Aug 1998, N. Piorski \& L. Pereira; MNRJ 51528, 1, 201.0 mm SL, municipality of Coroatá, rio Itapecuru, 1976, A. Barros (n/c 24); MNRJ 51529, 1, $274.0 \mathrm{~mm}$ SL, rio Mearim, no date, DNOCS (n/c102); MNRJ 51530, 1, 215.0 $\mathrm{mm}$ SL, rio Mearim, no date, DNOCS (n/c116). Piauí: LISDEBE 6976, 2, 221.0-229.0 mm SL, municipality of Aroazes, rio Tábua, 
tributary of rio Parnaíba, 1 Sep 1994, J. P. J. Filho; MZUSP 5101, 4, 61.0-114.0 mm SL, Teresina, rio Parnaíba, 16 Jun 1966, Expedição Depto de Zoologia; MCP 24967, 1, rio Pindaré, tributary of Mearim, West from Santa Inês, on the road Pará-Maranhão (BR 316), 24 Jul 1998, R. Reis, J. P. Silva, E. Pereira \& J. Montoya.

\section{Discussion}

On the color patterns of Schizodon species. Garavello (1994) discussed the color pattern of dark bars in Schizodon australis, S. borellii, S. corti, S. dissimilis, S. fasciatus, and $S$. intermedius. The six species together comprise the Schizodon fasciatus group defined by having dark brown bars throughout ontogeny, although the bars may vary in intensity. Schizodon fasciatus, S. australis and S. corti, exhibit four dark brown bars and an additional dark brown blotch on the caudal peduncle throughout their ontogeny. On the other hand, S. dissimilis, S. borellii, and S. intermedius never possess this dark brown caudal peduncle blotch at any stage of their development.

Sidlauskas et al. (2007) considered the horizontally striped color pattern of $S$. scotorhabdotus to be stable throughout its development but variable in intensity. That may well be true for the remaining species of Schizodon. Adults of other species, such as $S$. rostratus, S. nasutus, and $S$. altoparanae exhibit a dark brown horizontally elongated blotch on the base of caudal peduncle, differentiating them from S. jacuiensis, S. isognathous, and some specimens of $S$. knerii, which normally have an elongate mid-lateral dark stripe aligned with a shortened dark brown blotch at the lateral-line terminus. Schizodon knerii varies in color pattern, with some specimens having only three large inconspicuous brown bars on trunk, not combined with a horizontally elongate blotch on the caudal peduncle.

The similar color pattern of the transversally brown barred Schizodon resulted in misidentifications of species from distinct river basins. Besides Fowler (1941) and Roberts (1973), Sales et al. (1984) applied the name $S$. fasciatus to specimens from northeastern Brazil, which we consider to be $S$. dissimilis. The reference of Sarmiento et al. (2014) to S. dissimilis for the Bolivian Amazon drainages may be considered a misidentification. In addition, the barred Schizodon species from the Parana-Paraguay system was misidentified as $S$. fasciatum fasciatum by Ringuelet et al. (1967), using specimens from the Paraná River in Argentina, and also misidentified as Schizodon aff. dissimile by Géry et al. (1987) using specimens from the Paraguay river. This kind of error suggests that those authors did not recognize Schizodon borellii (Boulenger, 1900).

Schizodon dissimilis, S. borellii, and S. intermedius share the same color pattern, but recent molecular studies on Schizodon barred species (Santos, 2018 and Ramirez et al., in preparation) show separation among these three species. Evidence from the COI gene suggests a close relationship between $S$. borellii and S. intermedius, while $S$. dissimilis is genetically distant from these two species. These molecular analyses also suggest that the taxonomy of the barred Schizodon species-level still needs further study to elucidate the group's true diversity.

On the misidentifications of Schizodon barred species in Parana-Paraguay and northeastern basins. Géry (1987: 378) cited Schizodon aff. dissimile from the Paraguay River, perhaps misidentifying specimens of Schizodon borellii (Boulenger, 1900). The problem stems from Boulenger's (1895: 2, 3) description of the genus Nanognathus and species Nanognathus borellii based on a single specimen from "S. Pablo, Argentina". Later, Nanognathus was considered a synonym of Characidium (Crenuchidae: see Buckup in Reis et al., 2003: 88), and Characidium borellii is currently a valid species. A few years later, Boulenger (1900: 2) described Anostomus borellii based on a single specimen from Carandasinho (=Carandazinho), MT, Brazil, and this species is currently allocated to Schizodon (Anostomidae). Boulenger named both species after Alfredo Borelli, the collector of the type specimens in the Paraguay River system. The use of the same specific name for both species from the same river basin led to complex misconceptions concerning the barred species of Schizodon, as discussed below.

Eigenmann, Kennedy (1903: 512) identified specimens from the Paraguay River at Asuncion and Estancia La Armonia as Anostomus fasciatus (= Schizodon fasciatus) but Eigenmann, Ogle (1907: 7) later identified specimens from Paraguay as Anostomus borellii (= Schizodon borellii). Thus, Eigenmann apparently recognized that he had incorrectly identified the specimens in the first article co-authored with Kennedy.

Working with other collections from Paraguay, Eigenmann, McAtee, Ward (1907: 124) listed to "Nanognathus borelli" (=Characidium borellii) with reference to pl. 39, fig. 2. However, the figured specimen is a Schizodon, not a Characidium, and is correctly identified as "Schizodon borelli" in the legend (Eigenmann et al., 1907: pl 39, fig. 2). The authors knew how to identify Characidium, because Characidium fasciatum (Crenuchidae) is cited in the same work on the following page. Furthermore, Eigenmann et al. (1907: 124) listed Anostomus fasciatus Eigenmann, Kennedy (1903) in the synonymy of "Nanognathus borelli". Their comments on "Nanognathus borelli" mention another species of Schizodon, S. dissimilis, and not Characidium.

Myers (1950:196) wrote: "The fish which Eigenmann, McAtee, Ward call [Nanognathus] borelli has nothing to do with Boulenger's fish. I have examined Paraguayan specimens and the fish is close or identical with one of the Amazonian forms generally referred to Schizodon fasciatus. These comments are correct; the "Nanognathus borelli" of Eigenmann, McAtee, Ward is a species of Schizodon". Myers apparently was unaware that Boulenger (1900) had also described another species with the same trivial epithet, Anostomus (=Schizodon) borellii. As a result, Myers (1950) erroneously placed Nanognathus as synonym for Schizodon and overlooked the true concept of $S$. borellii established by Eigenmann, Ogle (1907: 7). 
Fowler (1950: 208) recognized Boulenger's species Anostomus borellii but reassigned it to the anostomid genus Laemolyta. Confusion persisted, however, as Fowler (1950: 254-255) correctly assigned Boulenger's Nanognathus borelli to Characidium, but accompanied it with an illustration based on the photo of Schizodon borelli in Eigenmann, McAtee, Ward (1907: pl. 39, fig. 2).

Géry (1977: 155) commented on Nanognathus borellii and Schizodon borellii, but apparently did not realize that the two names were applicable to separate species in the rio Paraguay basin. Later, Géry et al. (1987: 377) commented: «On notera qu'une erreur de Eigenmann et al. (1907: 124 et pl. 39) a causé une certaine confusion quant au statut de l'espèce of Characidiidae Nannostomus borelli Boulenger. Ces auteurs l'on en effet confondue avec S. fasciatus (cf. dissimile), au point de les mettre en synomye (l'espèce la plus récent étant ici prioritaire!) et en figurant, sous le non of Schizodon borelli Boulenger, un spécimen de S. dissimile (pl. 39, fig. 2)». Essentially, Géry et al. (1987) considered the specimen figured as Schizodon borelli by Eigenmann et al. (1907) to be Schizodon dissimile. Consequently, Géry et al. (1987: 377) identified their material from Paraguay as "Schizodon aff. dissimile". Their material is more likely to be Schizodon borellii, although specimens from tributaries of the Paraná might represent the species $S$. intermedius, which was subsequently described by Garavello, Britski (1990).

In conclusion, as herein understand, Nannognathus borellii (non Boulenger) Eigenmann, McAtee, Ward (1907) must be referred to Schizodon borellii (Boulenger, 1900). Furthermore, Eigenmann, Ogle (1907: 7) correctly considered Anostomus fasciatus (non Agassiz) Eigenmann, Kennedy, 1903 as Anostomus borellii Boulenger, 1900, a species subsequently transferred to Schizodon by Garavello, Britski (1990: 161).

Finally, we examined the specimens from Russas, Ceará, Brazil assigned to $S$. fasciatus by Fowler (1941: 175). Those specimens, ANSP 69491 (3) and ANSP 69494 (1), collected by Ihering in 1936 and sent to Fowler, are herein identified as S. dissimilis. Also, the specimen MCZ 46796 (1, cleared and stained), cited by Roberts (1973) as S. fasciatus is more likely S. dissimilis. Robert's specimen is from Parnaíba River in northeastern Brazil whereas $S$. fasciatus is native to the Amazon and north-flowing drainages of the Guyana Shield.

\section{On the geographic distribution of the Schizodon transversal} brown barred species. Garavello (1994: 187) discussed the disjoint distributions of the six species with dark bars: $S$. australis, $S$. borellii, $S$. corti, $S$. dissimilis, $S$. fasciatus, and $S$. intermedius. Schizodon dissimilis is restricted to the isolated northeastern rivers Itapecuru, Parnaíba, Mearim, Poti, and Jaguaribe, while $S$. corti is known only from the type locality in the Maracaibo drainage of Venezuela. Schizodon fasciatus occurs in the Guianas and throughout the upper and central Amazon in Peru, Colombia and Brazil. Schizodon borellii and $S$. intermedius are restricted to the Paraguay and upper Paraná basins, respectively, while $S$. australis is common in the Uruguay River.
Schizodon dissimilis, S. rostratus, and S. knerii occur in the north and northeastern rivers of Brazil and have distributions similar to the northeastern species of Curimatidae studied by Vari (1988). In that study, Vari (1988) revealed disjunct distributions for some curimatid genera that suggest two regions of endemism. Vari's northeastern area of endemism is marked by the endemic species Curimata macrops Eigenmann, Eigenmann, 1889 from the Parnaíba River and Psectrogaster saguiru (Fowler, 1941) from rivers of Ceará state. In addition, Fowler (1941: 175) reported Caenotropus labyrinthicus (Kner, 1858) from Parnaíba River, a species that Vari et al. (1995) also recognized from the Poti River. Vari's second area of endemism for Curimatidae extends from São Francisco to the coastal rivers of Rio de Janeiro.

The distribution of Schizodon dissimilis coincides with the northeastern endemic area proposed by Vari (1988) for curimatids. Furthermore, brown barred Schizodon species do not occur in the neighboring São Francisco River or in the isolated coastal basins from Bahia to Rio de Janeiro. However, other species of Anostomidae occur in both northeastern Brazil and in the São Francisco basin, such as Leporinus piau Fowler, 1941 and Leporinus taeniatus Lutken, 1875 (Birindelli et al., 2013), blurring the distinctiveness of those endemic areas. This is the expected pattern since, as showed by Dagosta, de Pinna (2017), all regions and South American basins are historically (and compositionally) hybrid. Their ichthyofaunal composition are mosaics of divergent elements of different origins, mostly from neighboring regions/basins.

\section{Comparative material examined. Schizodon altoparanae: Brazil:} Mato Grosso do Sul: MZUSP 41102, holotype, rio Paraná in front of Jupiá, 15-23 Nov 1962; MZUSP 41103 to 41120, paratypes, 28, same locality as holotype; LISDEBE 5830, 1, $230 \mathrm{~mm}$ SL, rio Baía, tributary of rio Paraná at Porto Primavera, Batayporã, 25 Jan 1993. São Paulo: MZUSP 41122, 3, rio Tietê, Barra Bonita, no date; MZUSP 4018, 1, 66 mm SL, rio Paraná, in front of Jupiá (ensecadeira number 1), Jupiá, 4 Dec 1960 [lat: -21.12 long: -51.77 WGS84]; LISDEBE 6983, 2, Ilha Solteira, rio Paraná, Ilha Solteira dam, Jul 1980. Paraguay: LISDEBE 6988, 4, 128.0-225.0 mm SL, Salto de Guairá, San Ramón, Limoy, Itaipu hydroelectric dam, no date. Schizodon australis: Brazil: Rio Grande do Sul: MCP 12931, holotype, São Nicolau, rio Uruguai, Santo Izidro, 3 Jan 1989. Paratypes: MCP, 1, 12793, São Nicolau, rio Uruguai, Santo Izidro, 4 Sep 1988; MCP 12936, 3, São Nicolau, rio Uruguai, Santo Izidro, 11 Mar 1989; MCP 12929, 2, Roque Gonzales, mouth of rio Ijuí, tributary of rio Uruguai, 3 Jan 1989; MCP 13279, 1, São Nicolau, rio Uruguai, Santo Izidro, 21 May 1989; MZUSP 47445, 1, São Nicolau, rio Uruguai, Santo Izidro, 3 Jan 1989; MZUSP 47446, 1, São Nicolau, rio Uruguai, Santo Izidro, 4 Nov 1988. Schizodon borellii: Brazil: Mato Grosso: MZUSP 2908, 1, Coxim, rio Piqueri, Oct 1930; MZUSP 62715, 1, Cuiabá, mouth of Varadouro, near 25 km from Barão de Melgaço, 3 May 1977; MZUSP 41146, 2, 290.0 298.0 mm SL, Cuiabá, rio Coxipó da Ponte, São Gonçalo, 16-22 Apr 1981; MZUSP 41147, 2, Cuiabá, rio Cuiabá, Sangradouro Grande, Barão de Melgaço, 15 Mar 1977; MZUSP 41148, 9, Miranda, marginal ponds of Transpantaneira road, 8-12 Nov 1981; MZUSP 
62439, 1, rio Cuiabá, Sangradouro Grande, Barão de Melgaço, 14-16 Mar 1977; MZUSP 62714, 2, rio Cuiabá, in front of Barão de Melgaço, 14 Feb 1978; MZUSP 41151, 1, Cuiabá, mouth of Croará, rio Cuiabá, 18-22 Apr 1981; LISDEBE 6982, 15, Poconé, marginal ponds of Transpantaneira, Nov 1978, LISDEBE 6977 , 13, Ilha Taiamã, rio Paraguay, 1-7 Dec 1980. Paraguay: MZUSP 41144, 4, rio Paraná, Porto Verde and creek Miguaçu, creek Itacoti and rio Monday, Jun/Jul 1977. Schizodon corti: Venezuela: USNM 121300, 1, $257.0 \mathrm{~mm}$ SL (Holotype of $S$. fasciatus corti), rio Palmar, near Totuma, about $100 \mathrm{~km} \mathrm{SW}$ of Maracaibo, Maracaibo basin. Schizodon fasciatus: Peru: Pucallpa, MZUSP 21464, 1, 191.0 mm SL, rio Ucayali, 2 Oct 1971. Brazil: Amazonas: MCZ 19365, 3, 172.0-224.0 mm SL, rio Içá; MCZ 19336, 3, 194.0-262.0 mm SL; MZUSP 20972, 15, 170.0-295.0 mm SL, Fonte Boa, Paraná of Iupiá, NW from Fonte Boa, 8-9 Oct 1968; MZUSP 7518, 5, 110.0130.0 mm SL, Paraná of Urucará, Urucará municipality, 9 Dec 1967; MZUSP 62720, 5, 115.0-240.0 mm SL, Lake Castro, Mouth of rio Purus, 7-8 Nov 1967; MZUSP 62722, 3, 240.0-275.0 mm SL, Lake Janauacá, right bank of rio Solimões, 7-25 Jan 1977; LISDEBE 6981 19, 94.4-316.0 mm SL, Lake Janauacá, rio Solimões, Inpa Research Base, 1978; Pará: MZUSP 9188, 3, 140.0-230.0 mm SL, rio Maicá, Santarem, 19-27 Oct 1971; Mato Grosso: MCZ 19329, 2, 100.0-285.0 mm SL, Vila Bela da Santíssima Trindade. Schizodon intermedius: Brazil: São Paulo: MZUSP 41123, 280.0 mm SL, holotype, Águas de São Pedro, stream tributary of rio Piracicaba, 23 Oct 1983; MZUSP 41125-41137, 145.0-280.0 mm SL, paratypes, rio Itaqueri, tributary of rio Piracicaba, Águas de São Pedro, São Paulo, 14 Jan 1983; LISDEBE 6984, 6, 210.0-291.0 mm SL, rio Jacaré Guaçu, near the bridge on road Gavião Peixoto to Boa Esperança do Sul, Araraquara, 17 Nov 1983. Schizodon isognathus: Brazil: Mato Grosso: MZUSP 4397, 1, 307.0 mm SL, Cuiabá, rio Cuiabá, Santo Antonio do Leverger, 1965; MZUSP 36719, 1, 176.0 mm SL, Itiquira, rio Piqueri, Porto Chinelo, farm Santo Antonio do Paraiso, 17-20 Sep 1980; LISDEBE 6977, 1, $230.0 \mathrm{~mm} \mathrm{SL}$, rio Paraguai, Ilha de Taiamã, 10 Aug 1980; LISDEBE 6978, 1, 207.0 mm SL, Cuiabá, São Gonçalo, rio Coxipó da Ponte, tributary of rio Cuiabá, 16-22 Apr 1981. Schizodon jacuiensis: Brazil: Rio Grande do Sul: MZUSP 38864, paratype, rio Guaíba, Morro do Sabiá, Porto Alegre, R. E. Reis, 25 Apr 1984 [lat: -30.13 long: -51.23 WGS84]; MZUSP 41126, 1, $216.0 \mathrm{~mm} \mathrm{SL}$, rio Paranhana, confluence with rio dos Sinos, near Taquara, 3-5 Jan 1979; MZUSP 62748, 2, 107.0 and $196.0 \mathrm{~mm}$ SL, rio Guaíba (Ponta Grossa), Porto Alegre, $8 \mathrm{Dec}$ 1964 [lat: -30.20 long: -51.27 WGS84]. Schizodon knerii: Brazil: Bahia: MZUSP 94051, 4, rio Formoso, tributary of rio Corrente, at Colônia do Formoso, Coribe, BA, 5 May 2007; LISDEBE 7001, 1, Rio São Francisco, 26 Jan 2014 [lat. -13.49 long. -43.44]; Minas Gerais: LISDEBE 7321, 2, Rio São Francisco, Três Marias, Morada Nova de Minas, 04-05 Oct 1982; LISDEBE 7322, 5, Três Marias Dam, Morada Nova de Minas, 05-07 Nov 1986; MZUSP 95159, 2 , Dam of Três Marias, rio São Francisco, 16 Jan 2007; MZUSP 51537, 5, Rio Paraopeba, lagoa Massacará, Fortuna de Minas, September 1994, [19³4'S 44³4'W]; MZUSP 73762, 1, Rio das Velhas, N. S. da Glória, at Caquende, Sto. Hipólito, Corinto, 18 Jun 1999 [18²4'56"S 44¹1'20"W]; MZUSP 90841, 1, Lagoa da Fazenda Boa Vista, at rio Bicudo, tributary of rio das Velhas, Corinto, 19 Apr 2005 [1807'22”'S 44³1'59”W]. Schizodon nasutus: Brazil: São Paulo:
MZUSP 2023, 5, 87.0-100.8 mm SL, rio Piracicaba, Piracicaba, Nov 1906; MZUSP 42844, 17, 96.0-206.0 mm SL, rio Paraná, Ilha Solteira, right bank of the river (ensecadeira) Ilha Solteira, 2528 May 1972; Minas Gerais: MZUSP 51457, 13, 98.0-115.0 mm SL, Itutinga dam, rio Grande, 23 Oct 1975; LISDEBE 6979, 3, 184.0-216.0 mm SL, Jaguara, rio Grande, downriver from Jaguara hydroelectric dam, 8-15 Feb 1989; LISDEBE 6980, 7, 204.0-252.0 $\mathrm{mm}$ SL, rio Grande, downriver from Jaguara hydroelectric dam, 8-15 Jul 1989. Schizodon platae: Argentina: MCZ 833, holotype, Rosário, La Plata; MZUSP 47691, 1, 102.0 mm SL, rio de La Plata (OSN Buenos Aires) Buenos Aires, 14 Oct 1965 [lat: -30.95 long: -55.70 WGS84]. Brazil: Rio Grande do Sul: MCP 12676, 1, Pirapô, mouth of rio Ijuí-Mirim, tributary of rio Ijuí, Uruguai river basin, 2 Nov 1988; MCP 12081, 1, São Borja, rio Uruguai at Garruchos, 9 Apr 1988; Paraná: MZUSP 21103, 1, rio Paraná, downriver from Sete Quedas, no date. Schizodon rostratus: Brazil: Piauí: MCZ 19380, Holotype, Rio Poti, tributary of Rio Parnaíba, Terezina (Rio Puty, Therezina), 1865; MCZ 69542, 8, Rio Poti, tributary of rio Parnaíba at Terezina (Rio Puty, Therezina), 1865. Schizodon scotorhabdotus: Venezuela, MZUSP 27969, paratypes, 3, 83.0-148.0 mm SL, caño to $\mathrm{W}$ of road from Calabozo to San Fernando, about $35 \mathrm{~km}$ to $\mathrm{S}$ of Masaquara farm (Canõ Falcon), 20 Jan 1983. Schizodon vittatus: Brazil: Pará: MZUSP 21334, 3, 173.0-192.0 mm SL, Tucurui, Lake near rio Tocantins, 29 Sep 1970; MZUSP 36835, 3, 149.0-252.0 mm SL, rio Xingu, Espelho falls, 23-26 Oct 1986; MZUSP 21263, 3, 128.0-159.0 mm SL, rio Tocantins, lake near Baião, between Baião and Tucurui, 11 Sep 1970; Goiás: MZUSP 26528, 1, 135 mm SL, rio Resende, tributary of rios Vermelho and Araguaia, near $10 \mathrm{~km}$ from Buenolândia, 7-13 Dec 1981; LISDEBE 6985, 2, 240.0-255.0 mm SL, rio Vermelho, tributary of Araguaia downriver from municipality of Goiás; Tocantins: LISDEBE 6986, 1, $275.0 \mathrm{~mm}$ SL, rio Tocantins between the rio Lageado mouth and Tocantinópolis, 14-18 Jun 1988; LISDEBE 6987, 5, 240-295 mm SL, rio Tocantins, between the rio Lageado mouth and Itaguatins, 7 Jun 1988.

\section{Acknowledgments}

The late Haroldo P. Travassos (in memoriam) loaned a large collection of MNRJ from northeastern river basins including specimens of Schizodon dissimilis; Osvaldo T. Oyakawa (MZUSP), Mary Anne Rogers and K. Swagel (FMNH), J. Lundberg and M. Sabaj (ANSP) also loaned specimens. Our late colleague Richard P. Vari (USNM) graciously provided access to the syntypes of $S$. dissimilis under his care; K. Hartel loaned and waited for the completion of our study on the MCZ syntypes of $S$. dissimilis for which we are deeply grateful. Andrew D. Williston (MCZ) provided the lectotype (MCZ19383) photograph. Special thanks to Oscar A. Shibatta (MZUEL) who helped with the sheared Principal Component Analysis. Mark H. Sabaj (ANSP), Jose L. Birindelli (MZUEL), Alexandre K. de Oliveira (UFSCar) and the anonymous referees read the manuscript and gave useful suggestions for which we are very grateful. Our gratitude also to Rodrigo T. Cardoso and Camila F. Perez for the preparation of the fish photos and map. The Biota-FAPESP Program (processes 2011/50213-5 and 2018/04388-7) supported this research. 


\section{References}

Abreu EL, Moura HFN, Lopes DS, Santos ACF, Câmara MM. Atividade pesqueira no cais do rio Poti, Teresina, PI: análise socioeconômica e diversidade de peixes. IV Congresso de Pesquisa e Inovação da Rede Norte e Nordeste de Educação Tecnológica Belém, PA. 2009; 1-11.

Birindelli JLO, Britski HA, Garavello JC. Two new species of Leporinus Agassiz (Characiformes: Anostomidae) from eastern basins of Brazil, and redescription of L. melanopleura Günther. Neotrop Ichthyol. 2013; 11(1):9-23. http://dx.doi.org/10.1590/ S1679-62252013000100002

Bookstein FL, Chernoff B, Elder RL, Humphries JM, Smith GR, Strauss R. Morphometrics in evolutionary biology: The geometry of size and shape change, with examples from fishes. Special Publication 15. Philadelphia: The Academy of Natural Sciences of Philadelphia; 1985.

Borodin NA. On the genus Anostomus (family Characinidae). Bull Mus Comp Zool. 1931; 72:37-52.

Boulenger GA. Viaggio del Dr. A. Borelli nel Matto Grosso e nel Paraguay. III. Liste des poissons recueillis à Urucum et à Carandasiñho, près de Corumbà. Boll Mus Zool Anat Comp Univ Torino. 1900; 15(370):1-4.

Britski HA, Garavello JC. Família Anostomidae. In: Buckup PA, Menezes NA, Ghazzi MS, editores (Eds.). Catálogo das espécies de peixes de água doce do Brasil. Rio de Janeiro: Museu Nacional; 2007. p.23-27.

Buckup PA. Family Crenuchidae. In: Reis RE, Kullander SO, Ferraris CJ, Jr., editors. Check list of the freshwater fishes of South and Central America. Porto Alegre: EDIPUCRS; 2003. p.87-95.

Dagosta FCP, de Pinna M. Biogeography of Amazonian fishes: deconstructing river basins as biogeographic units. Neotrop Ichthyol. 2017; 15(3):e170034. https://dx.doi. org/10.1590/1982-0224-20170034

Eigenmann $\mathrm{CH}$. Catalogue and bibliography of the freshwater fishes of the Americas south of the Tropic of Cancer. Lancaster: Press of the New Era Printing Co.; 1910. p.375-483.

Eigenmann $\mathrm{CH}$, Kennedy $\mathrm{CH}$. On a collection of fishes from Paraguay, with a synopsis of the American genera of cichlids. Proc Acad Nat Sci Philadelphia. 1903; 55:497-537.

Eigenmann CH., McAtee WL, Ward DP. On further collections of fishes from Paraguay. Ann Carnegie Mus. 1907; 4(2):110-57.

Eigenmann CH, Ogle F. An annotated list of characin fishes in the United States National Museum and the Museum of Indiana University, with descriptions of new species. Proc U. S. Natl Mus. 1907; 33(1556):1-36.

Fowler HW. A collection of fresh-water fishes obtained in eastern Brazil by Dr. Rodolpho Von Ihering. Proc Acad Nat Sci Philadelphia. 1941; 93:123-99.

Fowler HW. Os peixes de água doce do Brasil. Volume 1. Arq Zool (São Paulo). 1950; 6:205-404.

Fowler HW. Os peixes de água doce do Brasil. Arq Zool (São Paulo). 1954; 9:1-400.

Garavello JC. Descrição de uma nova espécie do gênero Schizodon Agassiz da bacia do Rio Uruguai, Brasil (Ostariophysi, Anostomidae). Comum Mus Cienc Tecnol Pucrs Ser Zool. 1994; 7:179-93.

Garavello JC, Britski HA. Duas novas espécies do gênero Schizodon Agassiz da bacia do alto Paraná, Brasil, América do Sul (Ostariophysi, Anostomidae). Naturalia. 1990; 15:153-70.

Garavello JC, Britski HA. Family Anostomidae. In: Reis RE, Kullander SO, Ferraris CJ, Jr., editors. Check list of the freshwater fishes of South and Central America. Porto Alegre: EDIPUCRS; 2003. p.71-84.
Garman S. On the species of the genus Anostomus. Bull Essex Inst. $1890 ; 22: 15-23$.

Géry J. Characoids of the world. Neptune City: TFH Publications, Inc. Ltd.; 1977.

Géry J, Mahnert V, Dlouhy C. Poissons characoides non characidae du Paraguay (Pisces, Ostariophysi). Rev Suisse Zool. 1987; 94:357-464.

Humphries JM, Bookstein FL, Chernoff B, Smith GR, Elder RL, Poss SG. Multivariate discrimination by shape in relation to size. Syst Biol. 1981;30(3):291-308. http://dx.doi.org/10.2307/2413251

Macleod N. Shear. Unique version. Ann Arbor: The University of Michigan Museum of Zoology. 1990. Fortran. MSDOS.

Myers GS. Studies on South American fresh-water fishes. II. The genera of anostomine characids. Stanford Ichthyol Bull. 1950; 3(4):184-98.

Ramos TPA, Ramos RTC, Ramos SAQA. Ichthyofauna of the Parnaíba river Basin, Northeastern Brazil. Biota Neotrop. 2014; 14(1):1-8. http://dx.doi.org/10.1590/S1676-06020140039

Ringuelet RA, Arámburu RH, Arámburu AA. 1967. Los peces argentinos de agua dulce. La Plata. Comisión de Investigaciones Científicas de la provincia de Buenos Aires. 602p.

Roberts TR. Osteology and relationships of the Prochilodontidae, a South American family of characoid fishes. Bull Mus Comp Zool. 1973; 145(4):213-35.

Sales AS, Nogueira JR, Lopes JP. Nota prévia sobre desova induzida do piau lavrado, Schizodon fasciatus (Agassiz, 1829), com o uso de hipófise de curimata comum, Prochilodus cearensis (Steindachner, 1911). Bol Tec - Dep Nac Obras Contra as Secas (Braz.). 1984; 42(1):1-115.

Santos CA. DNA Barcoding do gênero Schizodon (Characiformes, Anostomidae). [MSc. Dissertation]. São Carlos, SP: Universidade Federal de São Carlos; 2018.

Sidlauskas BL, Garavello JC, Jellen J. A new Schizodon (Characiformes: Anostomidae) from the Río Orinoco System, with a Redescription of $S$. isognathus from the Río Paraguay System. Copeia. 2007; 2007(3):711-25. https://doi org/10.1643/0045-8511(2007)2007[711:ANSCAF]2.0.CO;2

Sidlauskas BL, Vari RP. Phylogenetic relationships within the South American fish family Anostomidae (Teleostei, Ostariophysi, Characiformes). J Linn Soc London, Zool. 2008; 154:70-210. https://doi.org/10.1111/j.1096-3642.2008.00407.x

Spix JB, Agassiz L. Selecta genera et species piscium: quos in itinere per Brasiliam annis MDCCCXVII-MDCCCXX jussu et auspiciis Maximiliani Josephi I. colleget et pingendscuravit Dr. J. B. de Spix. Monachii; 1829.

Vari RP. The Curimatidae, a lowland Neotropical family (Pisces: Characiformes): Distribution, endemism, and phylogenetic biogeography. In Vanzolini PE, Heyer WR, editors. Neotropical distribution patterns: Proceedings of a workshop. Rio de Janeiro: Academia Brasileira de Ciências; 1988. p.313-48.

Vari RP, Howe JC. Catalog of type specimens of recent fishes in the National Museum of Natural History, Smithsonian Institution. 1. Characiformes (Teleostei, Ostariophysi). Smithson Contrib Zool 1991; 517:1-52.

Vari RP, Castro RMC, Raredon SJ. The neotropical fish family Chilodontidae (Teleostei: Characiformes): A phylogenetic study and a revision of Caenotropus Günther. Smithson Contrib Zool 1995; 577:1-32. https://doi.org/10.5479/ si.00810282.577 